\title{
AZ INFORMÁLIS KAPCSOLATI HÁLÓ ÉS A KOMPETENCIÁK - SZOCIOMETRIA ÉS 360 FOKOS ÉRTÉKELÉS ALKALMAZÁSA EGY FELSÖVEZETÖI TEAM VIZSGÁLATA SORÁN
}

A szerző dolgozatában egy szociometriai vizsgálatból és egy 360 fokos kompetenciaértékelésből származó adatok és megállapítások tapasztalatait foglalja össze. A kétféle megközelítés lehetőségeit kihasználva elsősorban arra a kérdésre kereste a választ, hogy az egyes személyeknek a vezetői csoportban elfoglalt szociometriai státusa milyen kapcsolatban van az illetőknek a 360 fokos értékelés által jelzett kompetenciaszintjével.

A vezetői csapatok sajátosságainak vizsgálata rendkívül tág terület, amelyen belül az elvi és gyakorlati megközelítésmódok, módszerek és eljárások sokasága található. Egyebek között ide sorolható a vezetésértékelés (Management Assessment, Management Audit) múfaja is, amely kifejezetten praktikus célokat szolgál, de adott esetben nagyon fejlett a tudományosság kritériumait is kielégítő módszertan alkalmazásával (Craig - Cooper De Backer, 1993). Közismertek a vezetők egyéni képességeit mérő pszichometriai eszközök (tesztek, kérdőívek), illetve az értékelés speciális szempontjai szerint strukturált interjúk (Hansen - Conrad, 1991).

A vezetésértékelések során, sajátságos módon alig kerül sor a szociometriai eljárás használatára, jóllehet a vezetésértékelés a vezetői teamek vizsgálatára irányul, a szociometria pedig kifejezetten a csoportszerkezet és csapatminőség elemzésének, illetve értékelésének eszköze (Mérei, 1988). A diagnosztikai eszközként méltatlanul elfeledett, de legalábbis háttérbe szorult szociometriával napjainkban a nagyon izgalmas kapcsolati háló elemzés keretei között találkozhatunk (Buchanan, 2003).

Az elmúlt években több vezetésértékelési projekt módszertanába építettük be a szociometriát, és tapasztalataink alapján meggyőződésünk, hogy az eljárás nélkülözhetetlen ahhoz, hogy a vezetés értékelése valóban teljes, hiteles és megbízható képet adhasson a vizsgált menedzsment kvalitásairól.
A szociometria természetesen nem önmagában, hanem egy tudatosan kialakított, komplex metodika részeként hatékony eljárás. Abban a vezetésértékelési projektben, amely ennek a tanulmánynak az alapjául szolgál, többféle eljárást kombináltunk: strukturált egyéni interjúkat, szervezeti kultúra kérdőívet, szociometriát és 360 fokos kompetenciaértékelést, amelyek együttesen rendkívül sok információt szolgáltattak mind az egyének, mind pedig a vezetői csapat jellemzőinek, minőségének megítéléséhez.

\section{Háttér: a szervezet és a vizsgált menedzsment}

Az említett komplex metodikával vizsgált menedzsment egy kiemelkedően profitábilis, magas szolgáltatási színvonalat nyújtó, fejlett informatikai háttérrel rendelkező, korszerú vállalkozást irányít. A cég a privatizációt követően teljes egészében külföldi tulajdonba került, de magyar vezetés alatt áll. A maga iparágában tőkeerejét és eredményességét tekintve egyaránt a piacvezetők közé tartozik, nemzetközi megítélése is igen kedvező. Tipikus nagyszervezet, országos hálózattal, jóval ezer feletti alkalmazotti létszámmal, széles ügyfélkörrel.

Természetesen ebben a vállalkozásban is megtalálhatók a szervezeti életciklus felnőtt korára jellemző tipikus problémák (Adizes, 1992). Ezzel együtt a cég mértékadó módon reprezentálja azokat a típusú piaci szereplőket, amelyek elterjedése nélkülözhetetlen ahhoz, hogy 
Magyarország tovább léphessen a fejlett piacgazdasággá válás útján. Éppen ezért, noha egyedi esetről van szó, a sikeres vállalkozást irányító menedzsment vizsgálatának tapasztalatai túlmutathatnak önmagukon.

A vezetésértékelés a cég legfelső és felső-középvezetői szintjein dolgozókra, összesen 21 személyre irányult. (A szervezet egészét tekintve, a különböző területeken és szinteken vezetői beosztásokban dolgozók száma ennél jóval nagyobb.) A 21 fős csoport tagjai egymáshoz viszonyítva négy hierarchikus szinten helyezhetők el, mindez jelzi, hogy a cég egésze hagyomá-nyos elvek szerint felépített, mélységében erősen tagolt szervezet. Hierarchikus szintek szerinti megoszlásukat az 1. táblázat (lásd a 40. oldalon) tartalmazza.

A szóban forgó vezetői kör tagjai igen komoly munkatapasztalatokkal rendelkeznek, hazai és nemzetközi mércével mérve is magasan kvalifikáltak.

- Átlagéletkoruk az adatfelvétel időszakában 48 év; a legalacsonyabb életkor 35 , a legmagasabb 60 , a szórás 7 év. A cégnél töltött munkaviszonyuk átlagos hossza 16 év; a legrövidebb munkaviszony hossza 4, a leghosszabb 37, a szórás 8 év.

- A 21 személy közül 8 fő több diplomával rendelkezik, 10-nek egyetemi, kettőnek pedig föiskolai végzettsége van; egy személy pontos adata nem ismeretes, de végzettsége bizonyosan felsőfokú.

- Mindössze ketten vannak közöttük, akik csak alapszintű idegen-nyelvismerettel rendelkeznek, a többség több nyelven is felső, illetve középszinten kommunikál. A szakmában hivatalos érintkezési nyelvnek számító angolt valamilyen szinten mindenki ismeri; 8 fő felső-, 11 közép-, 2 alapfokon.

A fent ismertetett adatok a hazai átlaghoz képest kiemelkedő (de az adott iparágban is magasnak számító) kvalifikációs szintet, a nemzetközi mércéhez való közeledést jeleznek. A vezetésértékelés szempontjából azonban arra is figyelmeztetnek, hogy az életkorilag meglehetősen homogén csoport frissítésre szorulna, a fiatalabb korosztályok másféle látásmódot, reflexeket, kultúrát képviselő tagjai köréből. Mint a később tárgyalandó adatokból látni fogjuk, a legfőbb deficitek éppen olyan kompetenciák terén vannak (pl. innovativitás, vállalkozó szellem, kezdeményezés, kockázatvállalás), amelyek szintje tipikus módon magasabb a fiatalabb, mint az idősebb évjáratú vezetők körében.

\section{A szociometriai vizsgálat eredményei}

A Mérei Ferenc koncepciójából kiinduló, több szempontú szociometria elvei szerint készült kérdőív (ld. Mérei, 1998: 114-116. old.) öt kérdést tartalma- zott. A személyes-szubjektív viszonylatok feltérképezésére szolgáló két választási kritérium a

- rokonszenv és a

- bizalom volt.

A funkció-szerep alapú választásokat három kritérium szerint kértük: kit/kiket tartanak a vizsgálat résztvevői egymás között

- a legelismertébb szakembernek, szaktekintélynek,

- a legnépszerübb vezetönek és

- a leginkább vállalkozó szellemünek.

A megadott instrukció szerint mindenki (mind az öt kritérium esetében) maximum három személyt választhatott. A 21 résztvevő túlnyomó többsége élt is ezzel a lehetőséggel.

A vezetői teamek szociometriai vizsgálatának alapkérdése, hogy elválik-e egymástól a személyes-szubjektív (rokonszenv-bizalom) alapú és a funkció-szerep (szakmai-vezetői) alapú kapcsolatrendszer. Másként fogalmazva: tudnak-e kellőképpen differenciálni a résztvevők a kétféle megítélésbeli szempont alapján, amikor az eltérő kritériumok szerint választaniuk kell egymás között.

Az optimális állapot egyik jellemzője, hogy a személyes-szubjektív alapú kapcsolatok áthatják a csoport egészét, sok a kölcsönös oldalirányú kapcsolat, és ha vannak is másoknál kedveltebb személyek, nincs sztárhelyzet, és nincsenek, vagy csak kevesen vannak, akik peremhelyzetbe kerülnek, vagy teljesen elszigetelődnek a csapaton belül. A másik jellemző a funkció-szerep alapú választások olyan mértékű koncentrálódása, aminek alapján kialakul a szakmai-vezetői képességek szerinti rangsor a csoport tagjai között. A személyes-szubjektív alapú választások a csoport szerkezetének oldalirányú, laterális dimenzióját, a funkció-szerep alapú választások pedig a hierarchikus dimenzióját alkotják.

A szubjektív-személyes alapon történő választásokat vizuálisan két ábra jeleníti meg. Az 1. ábra hagyományos szociogram, amin a csoport rokonszenvi és bizalmi kritériumok alapján kialakult rejtett kapcsolati hálózata rajzolódik ki. A 2. ábra ezt az informális kapcsolatrendszert a résztvevők közötti hierarchikus tagozódásra vetíti rá, azzal együtt mutatja be. Az egyes személyek esetében az A, B, C, D betűk a csoporton belüli hierarchikus tagozódás szintjeit jelölik, az 1 . táblázatnak megfelelően. A nagybetű melletti szám az illetőt azonosító sorszám az adott szervezeti szinten. Az adatok azt mutatják, hogy az adott személy hány százalékát kapta a rokonszenv, illetve a bizalom kapcsán kinyilvánított összes választásnak (szavazatnak). 


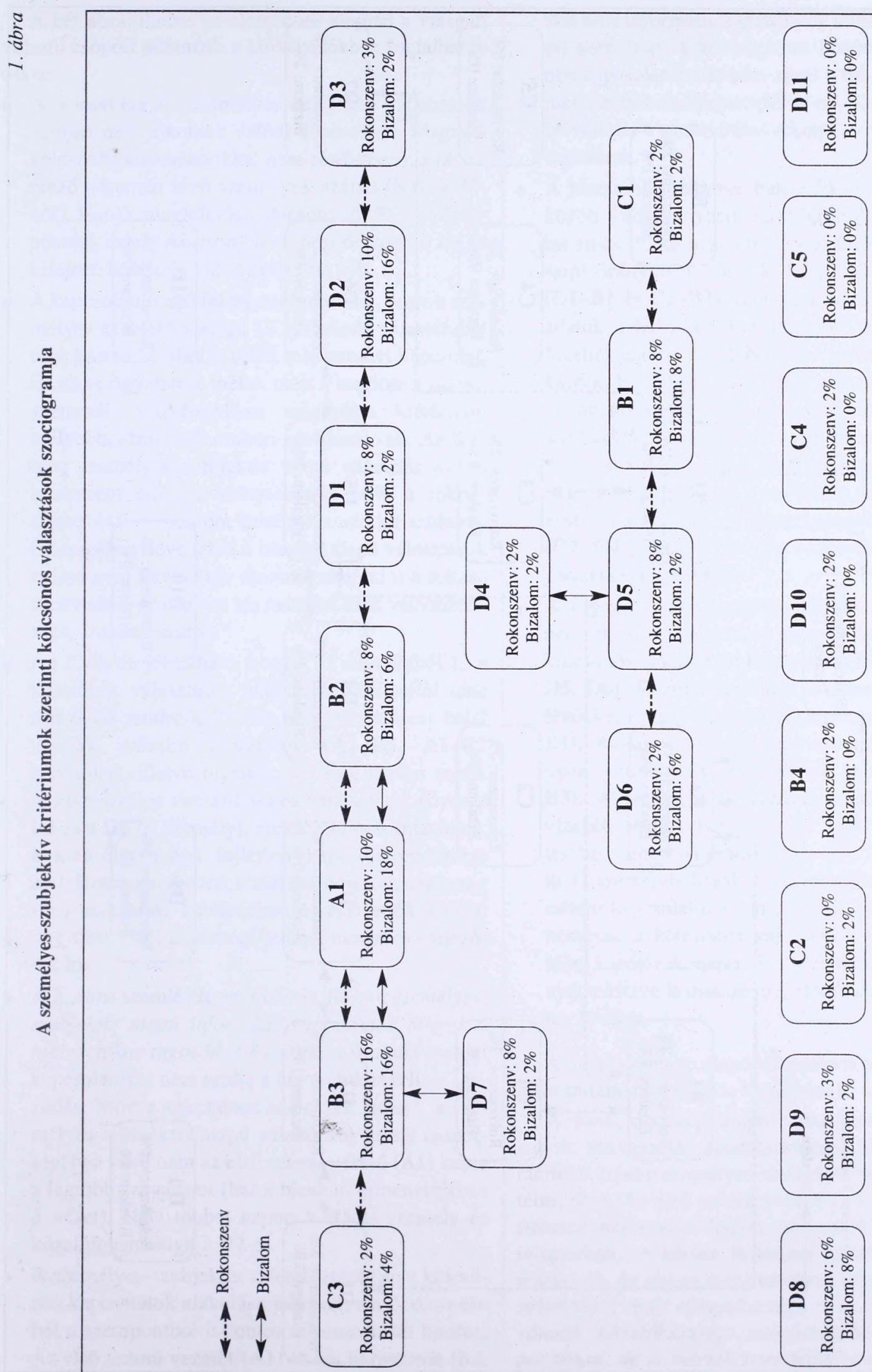




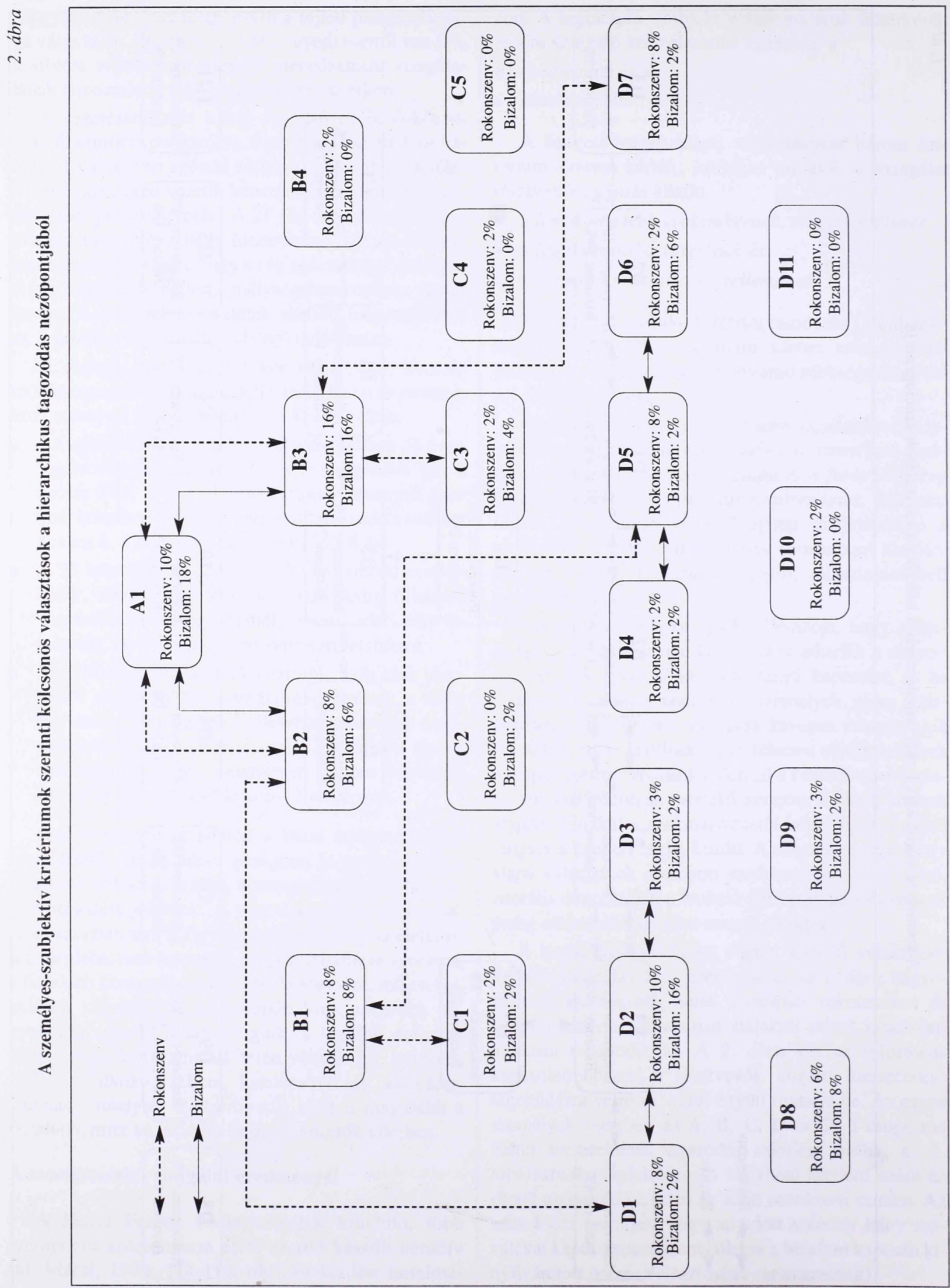


A két ábra, illetve az elemzések alapján a vizsgált vezetői csoport jellemzői a következőkben foglalhatók össze.

- A csoport tagjai a személyes-szubjektív választások alapján nem alkotnak valódi közösséget. Magas a kölcsönös kapcsolatokkal nem rendelkező, a társas mező peremén lévő személyek száma (8 fô a 21ből). Ennek megfelelően alacsony, $62 \%$, a kölcsönösségi index. Alacsony a csoport összetartó erejét kifejező kohéziós index értéke is: $6 \%$.

- A kapcsolati mező felszínességére utal, hogy a személyes-szubjektív alapú 13 kölcsönös választásból csak három bizalmi, a többi rokonszenvi kapcsolat. Ez azért figyelemre méltó, mert a bizalom a rokonszenvnél nyilvánvalóan szigorúbb kritérium, mélyebb, szorosabb emberi kötődésre vall. Az öszszes személyes-szubjektív alapú választás adatai korántsem ennyire aránytalanok: $56 \%$ a rokonszenv, $44 \%$ a bizalom kritériuma szerint született. Önmagában véve tehát a bizalmi alapú választások száma nem kevés (bár alacsonyabb, mint a rokonszenvieké), de nagyon kis mértékű ezek viszonzottsága, „találati aránya”.

- Az 1. ábrán jól látható, hogy a 21 személyből 13 a kölcsönös választások alapján két különálló lánc alakzatba rendeződik. Bár az egyik láncon belül vannak erôsebb kötődések (A1-B3, A1-B2 kapcsolat), illetve olyanok, akiknek három másik résztvevővel is van kölcsönös kapcsolatuk (ilyen a B3 és a D5-ös személy), ennek a fajta formációnak a kizárólagossága fejletlen kapcsolatrendszerre utal. Hiányoznak azok a zárt (háromszög, négyszög stb.) alakzatok, amelyekben a résztvevők közötti nagyobb fokú, közösségi jellegű integráció fejeződik ki.

- A 2. ábra szemléletesen mutatja, hogy a személyesszubjektív alapú informális kapcsolatok átlépik a hierarchikus tagozódás határait, a spontán emberi kapcsolatokat nem uralja a hierarchikus felfelé igazodás. Mint a százalékos adatokból látható, a személyes-szubjektív alapú választâsok közül összességében véve nem az első számú vezető (A1) kapta a legtöbb szavazatot (bár a bizalom dimenziójában ő vezet). Nála többet kapott a B3-as személy és közel ugyanannyit a D2-es.

- A személyes-szubjektív szférát legjobban a kölcsönös kapcsolatok alakulása jellemzi, s a 2. ábra ebből a szempontból is fontos információkat hordoz. Az első számú vezetôt (A1) és két helyettesét (B2,
B3) erős informális kapcsolatok kötik össze. Annak ellenére, hogy a két helyettes között nincs kölcsönös kapcsolat, tehát nem zárul a háromszög, a formális és informális pozíciókat együttesen figyelembe véve ez a triumvirátus alkotja a cég erős hatalmi centrumát.

- A hierarchiát tekintve harmadik, C szinten lévők között (oldalirányban) egyetlen kölcsönös kapcsolat sincs. Erről a szintről csak felfelé, a második szint irányában vannak kölcsönös kapcsolatok (C1-B1 és C3-B3). Ráadásul (amint a százalékos adatok jelzik), az ide tartozók rokonszenvi és bizalmi alapon meglehetősen kevés szavazatot is kaptak. Ez mindenképp elgondolkodtató, mert igaz ugyan, hogy az e szinten dolgozók egymástól eltérő területeket irányítanak, de a menedzsment egészébe azért be kellene, hogy illeszkedjenek. Úgy tűnik, hogy az integráció az ő esetükben sikerült a legkevésbé, hiszen az öt ide tartozó személy közül három (C2, C4, C5) a kölcsönös kapcsolatok hiányában peremhelyzetbe került.

- A negyedik, D szervezeti szinten sokkal jobb a helyzet. Az ide tartozó 11 személy közül 6-nak van kölcsönös oldalirányú kapcsolata (D1, D2, D3, D4, D5, D6). Közülük kettőnek a második, B szinten lévőkkel is van kölcsönös kapcsolata (D1-B2, D5B1). Rajtuk kívül még egy személy rendelkezik ilyen, felfelé irányuló kölcsönös kapcsolattal (D7B3). A negyedik szinten lévők integrálódása a vizsgált vezetői kör egészébe tehát sokkal erőteljesebb, mint a harmadikon lévőké. Jellemző, hogy itt 11 személyből csak 4 van peremhelyzetben, kölcsönös kapcsolatok híján. A negyedik szinten lévők nemcsak a kölcsönös választásokat, de az egyénileg kapott rokonszenvi és bizalmi szavazatok arányát tekintve is messze megelőzik a harmadik szinten lévőket.

A funkció-szerep alapú választások adatait a 2. táblázat tartalmazza (lásd a 40. oldalon).

A funkció-szerep alapú választások esetében a kapott szavazatok koncentrálódása jóval nagyobb mértékű, mint a személyes-szubjektív választások esetében volt. Az első számú vezető (A1) szociometriai státusza (helyezése a kapott szavazatok száma szerinti rangsorban), a három kritérium mindegyikében kiemelkedő. Az ebben megmutatkozó egységes csoportvélemény a vezér elfogadottsága és az iránta megnyilvánuló követőkészség szempontjából bizonyosan pozitivum, de a mérték nem feltétlenül kedvező. Az 
ilyen szituációban ugyanis benne rejlik annak a lehetősége, hogy a csoporttagok egy része kevésbé mozgósítja energiáit, passzív-végrehajtói szerepbe húzódik vissza, és lehetőség szerint minden iránymutatást, felelősséget, döntést az első emberre hárít át. Nyilvánvalóan veszélyesebb lenne a rivalizálás, de a „one man show" is kockázatos és szervezeti hatékonyságot rontó tényező (elegendő csak a felfelé tolt döntések közismert negatívumaira utalni.)

A vizsgált vezetői csoport legfőbb gyengesége, hogy sokan vannak, akik egyetlen szavazatot sem kaptak a három funkció-szerep alapú kritérium szerint. A 2. táblázatból látható, hogy a 21 személy közül nyolcat senki nem sorolt az elismert szakemberek közé, 8 nem kapott egyetlen szavazatot sem, mint népszerű vezető, 7 személyt pedig senki sem jelölt meg vállalkozó szelleműként. A kedvezőtlen megítélés ráadásul halmozódik is, mert két olyan személy van, akik a három kritérium egyikében sem kapott egyetlen szavazatot sem (D4, D10), és hat olyan, akik két kritérium egyikében sem kaptak szavazatot (B1, C1, D2, D8, D9, D11).

További problémát jelez, hogy a szavazatot nem kapott, másként fogalmazva a funkció-szerep alapú kritériumok szerint alacsony szociometriai státusú személyek között felülreprezentáltak a hierarchia magasabb szintjein lévők. A hierarchia második, B szintjén lévő négy vezető közül három, a következő, C szinten lévő öt vezetőből négy tartozik az alacsony szociometriai pozícióban lévők közé a funkció-szerep alapú kritériumok szerint. Relatíve legjobb helyzetben a vizsgált csoporton belül legalacsonyabban, $\mathbf{D}$ szinten lévők vannak, mert az ide tartozó 11 fő közül hat került az alacsony szociometriai pozícióban lévôk csoportjába. Az is igaz viszont, hogy közülük kettő (a fentebb említett D4, D10) mindhárom kritériumban nulla szavazatot kapott.

A személyes-szubjektív és a funkció-szerep alapon született választásoknak egyetlen változóban való kezelhetősége érdekében az öt kritériumból egy Likertskálát készítettünk. A megbízhatósági szintet kifejező Cronbach-alfa értéke 0,836 , vagyis az öt kritérium információtartalmának túlnyomó részét megőrző skála megalapozottan használható a további elemzés céljaira. A Likert-skála értékeit kvartilisekbe soroltuk, amivel megkaptuk a vizsgált személyek összesített szociometriai státushierarchiáját. Ennek ismeretében lehetőség van annak tesztelésére, hogy a szervezeti hierarchiában elfoglalt hely és a szociometriai státushierarchiában elfoglalt hely milyen kapcsolatban áll egymással.
Az elemzések azt mutatják, hogy a vizsgált személyek esetében a két dimenzió lényegében véve független egymástól. A kapcsolatukat mérő Spearmanféle rangkorrelációs együttható gyenge $(0,308)$ nem szignifikáns ( $\mathrm{p}=0,174)$ összefüggést jelez. Ez másként fogalmazva azt jelenti, hogy az egyes személyeknek az adott vezetői csapat társas kapcsolati hálózatában elfoglalt helye nem függvénye annak, hogy az illetök hol helyezkednek el a csoporton belüli szervezeti hierarchiában, hivatali ranglétrán. A számszerü eredményeket a 3. táblázat (lásd a 41. oldalon) foglalja össze és a 3. ábra teszi szemléletessé.

A 3. ábrából azt érdemes kiemelni, hogy a személyes-szubjektív alapú kölcsönös kapcsolatok jellemzó módon átlépik a szociometriai státushierarchia (illetve az ennek megfelelö kvartilisek) határait. Csak a negyedik (legfelső) kvartilisbe tartozók esetében vannak egymás közti (szociometriai státuscsoporton belüli) oldalirányú kapcsolatok (B3-A1). A másik három kvartilis egyikében sincsenek ilyen relációk, a kölcsönös kapcsolatok az eltéró szociometriai státuscsoportokhoz tartozók között (vertikális irányban) alakultak ki.

Megjegyzendő még, hogy bár peremhelyzetben lévők (személyes-szubjektív alapú kölcsönös kapcsolatokkal nem rendelkezők) mindegyik kvartilisben vannak, ezek száma, illetve aránya messze a legalsó kvartilisben (a szociometriai státushierarchia alján) a legmagasabb. Az ide tartozó, teljesen perifériára szorult négy személy (D10, C5, D9, D11) esetében felmerül a kérdés, hogy vajon milyen értelemben képesek egyáltalán a csoport munkájában részt venni, illetve milyen befolyást gyakorolhatnak a menedzsmentteam tevékenységének színvonalára, hatékonyságára.

\section{A 360 fokos kompetenciaértékelés metodikája és eredményei}

A kompetenciák vizsgálatának, ezen belül a 360 fokos értékelésnek és visszajelzésnek széles körű szakirodalma és kiterjedt gyakorlata van. A kompetenciák elméletének és a kompetenciamodellek készítésének ismeretében (Boyatzis, 1982; Spencer - Spencer, 1993) bármely szervezet átveheti vagy kialakíthatja magának azt a kompetenciakészletet, ami sajátosságainak leginkább megfelel (The 2nd International Competency Conférence, 1997). Ha a szervezet készen áll, érett az eljárásra, (Koebelin, 1999), akkor a kompetenciák 360 fokos perspektívából történő vizsgálata nagyon hatásos eszköz lehet a vezetői csapattagok különféle készségeinek, képességeinek, jártasságainak felméréséhez, és a fejlesztési szükségletek pontos meghatározásához. 


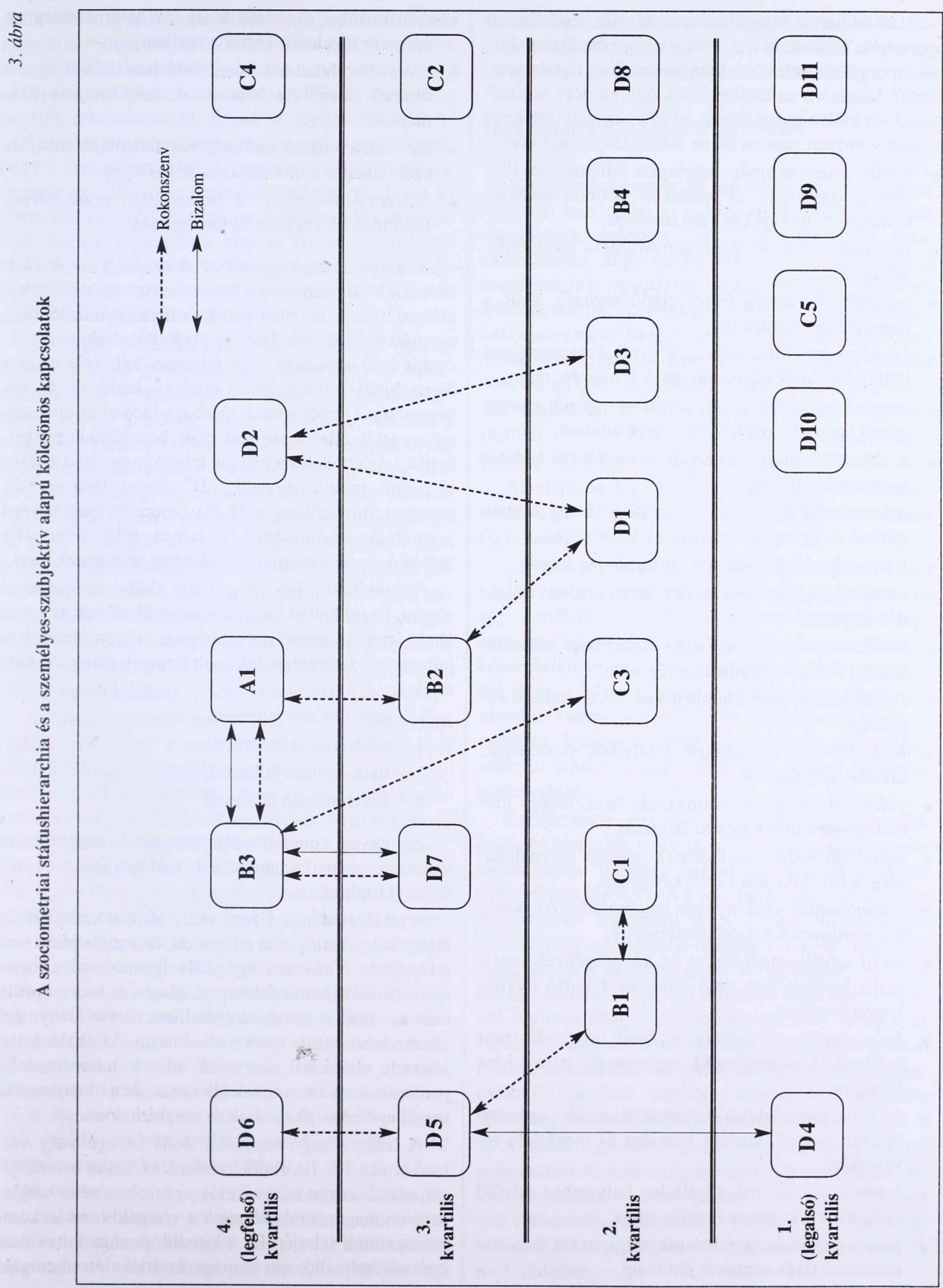


Esetünkben a vizsgált szervezet már rendelkezett egy olyan listával, ami a tevékenysége és sajátosságai szempontjából releváns kompetenciákat tartalmazta. Ebből kiindulva az értékelőknek egy kérdőív segítségével azt kellett megítélniük, hogy a vizsgált (értékelt) személy milyen szinten áll az alábbi tényezők terén:

- eredményorientáltság: mennyire jellemző az illetőre az önmagán és másokon számon kérhető, konkrét eredményekre való törekvés,

- vállalkozó szellem, kockázatvállalás a siker érdekében,

- minőség, kiválóság iránti elkötelezettség, akár a mennyiség rovására is,

- kockázat-megitélési képesség: érzék és tapasztalat a különböző kockázatok súlyának felmérése terén,

- iparági szemlélet: a cég tevékenységének iparági szintű ismerete, összefüggéseinek átlátása,

- szakterületi tudás: elmélyült és naprakész tudás a saját szakterületen,

- üzletorientáció: az üzleti lehetőségek tág körben történő és gyors felismerésének képessége,

- felelősségvállalás minden körülmények között,

- hitelesség: konzekvensen őszinte és hiteles viselkedés másokkal szemben,

- elkötelezettség: tettekben megmutatkozó elkötelezettség és áldozatvállalás a cég iránt,

- rugalmasság, jó értelemben vett alkalmazkodó képesség,

- innovativitás: újdonságok kitalálása, bevezetése, kreatív megoldások,

- változáskezelés: a változások bevezetése, menedzselése terén mutatott jártasság,

- fejlődő képesség: az illetőnek önmaga meghaladására, a továbblépésre való képessége,

- csapatmunka: gyakorlatban megmutatkozó készség a csapatmunkára, együttmúködésre,

- külső ügyfél-orientáltság: az ügyféligények maximális kielégítésére való törekvés a külső ügyfélkapcsolatokban,

- belső ügyfél-orientáltság: a „belső ügyfelek” (más területek képviselőinek) egyenrangú partnerként kezelése,

- információtovábbitás, információkezelés: az információk pontos, korrekt kezelése és megfelelő továbbítása,

- kommunikációs stílus: minden helyzetben odaillő és hatékony kommunikációs stílus,

- munkaszervezés: a feladatok megosztása és a koordináció terén mutatott jártasság,
- operativitás: gyakorlatiasság és határozottság az operatív feladatok végrehajtásában,

- delegálás: feladatok megfelelő hatáskörrel együtt történő delegálása beosztottak, munkatársak számára,

- motiválás: mások szükségletei felismerésének, és ezen alapuló motiválásának képessége,

- fejlesztés-támogatás: a beosztottak, munkatársak fejlődésének segítése és țámogatása.

A vizsgálat sajátosságát az adta, hogy az értékelt személyek valamennyien a szociometriai vizsgálatnak is alanyai voltak, emellett pedig (különféle relációkban) egymást is értékelték. Néhány kivételtől eltekintve mindenkit öten értékeltek; egy felettese, két, vele azonos hierarchikus szinten lévő (oldalági) kollégája és két beosztottja. (Ebből a megoldásból adódóan az első számú vezetőt értelemszerūen csak beosztottak értékelhették.) Az értékelt személyek többsége egyúttal értékelő is volt, csak a negyedik, „D” szinten lévő vezetők esetében volt szükség a 21 fős csoportba nem tartozó személyek bevonására, beosztotti relációban. (Ez utóbbiak a szociometriai vizsgálatban nem vettek részt.)

$\mathrm{Az}$ értékelés egy négyfokú skála segítségével történt. Ezzel kellett kifejeznie az értékelőnek, hogy az általa értékelt személyre mennyire, milyen mértékben jellemzőek a korábban felsorolt kompetenciák. A skála értékei:

1 - mérsékelten jellemző,

2 - többnyire jellemző,

3 - határozottan jellemző,

4 - maximálisan jellemző.

Az egyes kompetenciák szintjének megítélésére vonatkozó átfogó adatokat a 4. táblázat (lás a 41. oldalon) tartalmazza.

A táblázat alapját a fenti skála alapján számított átlagértékek alkotják, ami elfogadott, de nem teljesen korrekt eljárás. A szóban forgó skála ugyanis csak az ordinális mérési szintnek felel meg, átlagot és szórást pedig csak az ennél magasabb intervallum, illetve arányméró szinten lehet egzakt módon alkalmazni. Az általunk (is) követett eljárásból származó adatok tehát kevésbé pontosak, mint amilyennek látszanak, de a fő tendenciák megállapítására alkalmasak és megbízhatóak.

A szóban forgó négyfokú skála közepe vagy várható értéke 2,5. Ha ebből indulunk ki, akkor a 4. táblázat adatai szerint az értékelők egészében véve meglehetősen magasra minősítették a vizsgált vezetők kompetenciáinak szintjét. Ez a kiindulópont azonban nem egészen helytálló, mivel maga az értékelésre szolgáló 
skála sem kiegyensúlyozott, hanem a pozitív értékelés irányába, felfelé torzít. Alkalmazását egy fontos kérdezéstechnikai szempont indokolta, nevezetesen, hogy az ilyesfajta eljárás során az értékelők óvakodnak a negatív minősítésektől. Ennek a szempontnak a figyelembevétele némiképp analóg azzal a gyakorlattal, hogy a szociometriai kérdőívekben is ritkán kerül sor negatív kritériumok megfogalmazására (pl. hogy ki ellenszenves vagy alkalmatlan valamire.) De ahogyan csak pozitív kritériumok alapján fel lehet tárni egy csoport rejtett hálózatát, ugyanúgy kimutatható a kompetenciák csoportjának belső tagozódása, a felfelé torzító skála alkalmazása ellenére is.

A vizsgált menedzsment (alapvetően saját önértékelése szerinti) gyengeségei: a motiválás, az üzletorientáció, a kommunikációs stílus, a rugalmasságalkalmazkodó képesség, az innovativitás, valamint a vállalkozó szellem-kockázatvállalás. Mindegyik olyan kompetencia, amelyekre alapvető szükség van a modern piacgazdaság versenykörülményei között vezetett vállalatoknál. Ezen a ponton érdemes emlékeztetni arra, hogy a vizsgált menedzsment az irányított vállalkozás eredményességét és az egyéni kvalifikációs paramétereket tekintve egyaránt az iparág élvonalába tartozik. Ebből a szempontból nézve a (relatív) gyengeségként érzékelt kompetenciák fejlesztése egyúttal olyan tartalék is, aminek mozgósításával a cég még inkább megszilárdíthatja pozícióit a versenypiacon.

Az összes értékelő adatai alapján a menedzsment legfőbb erősségei: a szakterületi tudás, a cég iránti elkötelezettség, az ügyfél- és az eredményorientáltság. Ezek fontos kompetenciák ugyan, de az utánuk következők közül jó néhánynak ugyancsak feljebb kellene kerülnie az erősségek listáján. Ilyen az iparági szemlélet, ami lényegében véve a tágabb környezeti öszsżefüggésekben való, stratégiai gondolkodás képességének felel meg. Multinacionális vállalati környezetben tipikus kompetencia pl. a még ennél is átfogóbb megközelítést magában foglaló, globális gondolkodás. A fejlett piacgazdaságok menedzsmentjében a minöség, kiválóság iránti elkötelezettség a legfontosabb kompetenciák (egyúttal vállalati kulturális értékek) közé tartozik (Peters - Waterman, 1986), de ugyanez elmondható a csapatmunkáról és az üzletorientáltságról is. Ezeknek a kompetenciáknak a kapcsán ugyancsak érződik több-kevesebb elmaradás a fejlett világ menedzsmentgyakorlatához képest.

Mindenesetre a vizsgált vezetői csoport életkori és szakmai-kvalifikációs jellemzőinek ismeretében a 4 . táblázat alapján érzékelhető, hogy a jól felkészült és tapasztalt, de már szakmai pályafutása delelőjén lévő menedzsmentnek milyen vonatkozásban lenne szüksége a megújulásra egy következő generáció kívánatos kompetenciákat hordozó tagjainak bevonásával.

\section{Tendenciák a 360 fokos értékelésben}

Mielőtt a kompetenciák szintjének és a csoportban elfoglalt szociometriai státusnak az összefüggéseit vizsgálnánk, érdemes egy kis kitérôt tenni azzal kapcsolatban, hogy milyen tendenciák jelentkeztek a kompetenciák megitélése terén az egyes értékelöi relációk szerint. Az értékelői reláció kifejezés használatára azért van szükség, mert a 360 fokos metodikából adódóan az értékelők személye túlnyomórészt azonos volt, de az egymás értékelésében betöltött viszonylataik szerint különböztek egymástól, illetve egy-egy személy több relációban (felettesként, egyenrangú, oldalági vezetőként és beosztottként) is értékelt.

Az alapadatokat az 5. táblázat (lásd a 42. oldalon) tartalmazza, és az adatok két szempontból érdemelnek figyelmet.

Az egyik, hogy az összes értékelő által adott átlagadatok jelentős mértékben eltérnek, szóródnak az egyes értékelői relációk szerint. Fogalmazhatunk úgy is, hogy megjelennek, láthatóvá válnak a pozitiv összképen belüli, esetenként eléggé erős, markáns árnyalatok. Erre a legjobb példát a vizsgált vezetés gyengeségeinek számító kompetenciák szolgáltatják, amelyek esetében a felettesi és föleg az oldalági relációkban született adatok hellyel-közzel már érdemi kritikáról tanúskodnak.

Emlékeztetve arra, hogy a skála középértéke 2,5, érdemes kiemelni, hogy pl. a motiválás kompetenciájának szintje oldalági értékelői relációból 2,36, az üzletorientációé 2,27. A kommunikációs stílusé felettes értékelői relációból 2,33, a rugalmasság-alkalmazkodó képesség szintje oldalági értékelői relációból 2,28, az innovativitásé 2,23. A vállalkozó szellemkockázatvállalás esetében a felettes értékelői relációból született átlag 2,23, az oldalági adat pedig csak 1,98. Az, hogy az összes értékelő átlagadatai ezeknél jobbak, minden esetben annak köszönhető, hogy a beosztotti relációból végzett értékelés kedvezőbbnek ítélte meg a szóban forgó kompetenciákat.

A másik figyelemre méltó dolog az, hogy a kompetenciák szintjének az egyes értékelői relációkból történő megítélése olyan mértékben eltér egymástól, ami már valószínúleg nem írható a véletlen számlájára. Ezt illusztrálják a 6.1., 6.2. és 6.3. táblázatok (lásd a 42. és a 43. oldalon). 
$\mathrm{Az}$ adatok tehát arra vallanak, hogy (relative) legszigorúbban az oldalági relációból értékelők minősitették az értékelendö személyeket. Hozzájuk képest kedvezőbbek a felettesi relációból történö megitélések, a legpozitívabb minósitések pedig a beosztotti relációban születtek. A jelenséggel kapcsolatban két feltételezést tudunk megfogalmazni. Az egyik, hogy az oldalági értékelői relációkban érzékelhetô kritikusság esetleg valamiféle (rejtett) rivalizálás kifejeződése lehet. A másik, hogy az értékelt személyeknek a beosztotti relációkból történő kedvezőbb megítélése mögött néminemű behódolás húzódhat meg. Megjegyzendő, hogy ilyesféle tendenciákat más szervezetek felső szintű vezetésének ugyanilyen, 360 fokos eljárással történő vizsgálata során is tapasztaltunk. Mivel ennek a metodikának az alkalmazása eléggé széles körben terjed, érdemes lenne alaposabb kutatásokat végezni a különböző értékelői relációkból származó adatok belső összefüggéseinek feltárása, végső soron az eljárás érvényességének és megbízhatóságának vizsgálata céljából.

\section{A szociometriai státus és a kompetenciaszintek összefüggései}

Mint a 7. táblázat (lásd a 43. oldalon) adataiból látható, a legmagasabb és a legalacsonyabb szociometriai státusú személyek (3. ábra) kompetenciáinak átlagpont-értékei az esetek túlnyomó többségét tekintve jelentősen eltérnek egymástól.

A 24 kompetencia közül 17-ben a legmagasabb szociometriai státusúak kompetencia-átlagai szignifikáns mértékben (legalább 0,2-del) magasabbak, mint a legalacsonyabb státusúaké. (Egy kompetencia, a delegálás esetében a különbség fordított, e tekintetben tehát a legalacsonyabb szociometriai státusúak kompetenciaszintjét ítélték erősebbnek az értékelők.) $A$ vizsgált vezetöi teamre vonatkozóan megállapitható, hogy akik az informális kapcsolati hálózatban a legelfogadottabb személyek közé tartoznak, azok testesitik meg egyúttal a kompetenciák legmagasabb szintjét is.

A legmagasabb szociometriai státusúakról feltételezhető, hogy valamilyen mértékben mintaadók, vonatkoztatási személyek a többiek számára - legalábbis a csoport perifériájára kerültekhez képest. Ezen az alapon a nekik tulajdonított különösen magas szintű kompetenciák arra is utalhatnak, hogy mi lenne kívánatos, követendő a vezetői team egésze számára.

A korábbi adatokból tudjuk, hogy a magas szociometriai státusúak közül is kiemelkedik az A1-gyel jelölt első számú vezető, különösen a funkció-szerep kritériumokra kapott választások alapján. Érdemes tehát megvizsgálni, hogy az ő kompetenciáinak szintje hogyan viszonyul azokéhoz, akik (rajta kívül még négyen) a legmagasabb szociometriai státusú csoportot alkotják. Az adatokat a 8. táblázat (lásd a 44. oldalon) tartalmazza; ebben az első számú vezető kompetenciaátlagainak csökkenő sorrendjében szerepelnek az egyes kompetenciák.

Nagyon jól látható, hogy a kompetenciák java részében (a 24-ből 14 esetben) az első számú vezetôre vonatkozó értékelések átlaga húzta fel jelentös mértékben a legmagasabb szociometriai státusú (vele együtt ötfős) csoport kompetenciaszintjének átlagát. Különösen markánsan érvényesül ez az iparági szemlélet, a vállalkozó szellem - kockázatvállalás és az üzleti orientáció esetében, de az első számú vezetônek tulajdonított magas kompetenciaszint érvényesül az operativitás, az innovativitás, az eredményorientáltság, a felelősségvállalás, a kockázat-megitélési és a fejlödö képesség terén is, ha a legmagasabb szociometriai státusúak csoportjába ôt is beszámítjuk (lásd a 7. táblázat adatai).

Úgy tűnik tehát, hogy ahogyan az Al-es személyt a vezetöi team informálisan is maga fölé emeli, a kompetenciák túlnyomó többségének esetében is benne látják megtestesülni a legmagasabb szintet és az ebböl adódóan követendö példát.

Fel kell azonban figyelni arra, hogy a rajta kívül legmagasabb szociometriai státusú négy személyhez viszonyítva az első számú vezetőnek nem jelentéktelen fogyatékosságai is vannak. Az értékelőitől kapott átlagok ugyanis szignifikáns mértékben alacsonyabbak az említettekéhez képest a következő kompetenciák esetében:

\section{- minőség,}

- kiválóság iránti elkötelezettség

- belső ügyfél-orientáltság,

- információtovábbítás-információkezelés,

- csapatmunka.

Ebben az értékelésben mintha az a kritika fogalmazódna meg, hogy egy kétségkívül elismert szakember és üzletember a maga individuális kvalitásait a tőle elvártnál kevésbé kamatoztatja a minőségre való törekvés terén, a mennyiségi szemlélettel szemben; hogy a belsô ügyfeleket (értsd: a különböző rendű és rangú munkatársait, kollégáit) nem tekinti úgy partnereinek, ahogyan azok szeretnék; hogy nem adja meg az elvárt mennyiségű információt; és egészében véve kevésbé csapatjátékos, mint ahogyan azt elvárnák tőle. Ez az értékelés pontszámainak alakulásából felsejlő kritika a 
másik oldala annak a „one man show” jelenségnek, amire korábban, az első számú vezető vezérként való elfogadottsága kapcsán utaltunk.

\section{Összefoglalás}

A legfőbb módszertani tapasztalat az, hogy a szociometria és a 360 fokos értékelési eljárás együttes alkalmazása jelentősen megnöveli a vezetői teamek értékelésének megbízhatóságát. Ennek révén pedig hatékonyabbá tehetők mind a vezetői csapat összetartó erejének (csoportkohéziójának) növelésére, mind pedig az egyéni szinten szükséges kompetenciák fejlesztésére irányuló törekvések. Nagymértékben növelné az értékelések objektivitását és pontosságát, ha az ilyen jellegű vizsgálatok (illetve az erre irányuló kutatások) adatainak alapján sor kerülhetne a számszerű mutatók, indexek olyasféle standardizálására, mint ami a pszichometriai tesztek esetében szokásos.

Ami a hasznositást illeti, a szociometriai eljárás egyik fő eredménye a centrális helyzetben lévők (magas szociometriai státusúak) azonosítása, akik szociális elfogadottságuk révén pozitív mintaadó szerepet tölthetnek be a vezető csoporton belül. Legalább ennyire fontos eredmény azonban annak kimutatása is, hogy kik szorultak a vezetői team perifériájára, mivel az ő esetükben van leginkább szükség a fejlesztői orientáltságú beavatkozásra. Elő kell segíteni a kap- csolati hálózatba való jobb integrációt (csapatépítés, szervezetfejlesztés) és támogatni kell őket az egyes kompetenciák terén meglévő hiányosságok felszámolásban (tréning, coaching). Így válhat a szociometria és a 360 fokos értékelés együttes alkalmazása a vezetői csapat egészére, ezen belül pedig az egyes személyekre irányuló céltudatos fejlesztés hatékony eszközévé.

\section{Felhasznált irodalom}

Adizes, I. (1992): Vállalatok életciklusai - Hogyan és miért növekednek és halnak meg vállalatok és mi az ezzel kapcsolatos teendô? HVG Rt., Budapest

Boyatzis, R. E. (1982): The competent manager - A model for Effective Performance; A Wiley-Interscience Publication, New York

Buchanan, M. (2003): Nexus, avagy kicsi a világ - A hálózatok úttörő tudománya; Typotex kiadó, Budapest

Craig-Cooper, M. - De Backer, Ph. (1993): The Management Audit - How to Create an Effective Management Team; Pitman Publishing, London

Hansen, C. P. - Conrad, K.A. (eds) (1991): A Handbook of Psychological Assessment in Business; Quorum Books, New York

Koebelin, G. (1997): Are you ready for 360 Spring, Suffolk University

Mérei, F. (1988): Közösségek rejtett hálózata - A szociometriai értelmezés, Tömegkommunikációs Kutatóközpont, Budapest

Spencer L. M. - Spencer S. M. (1993): Competence at Work Models for Superior Performance; John Wiley \& Sons, Inc. New York

The 2nd International Competency Conference (1997): Competency Bibliography and Resource Guide 


\section{Táblázatok}

1. táblázat

A vizsgált vezetői team belső hierarchikus megoszlása

\begin{tabular}{|l|c|c|}
\hline Vezetői szintek & Jelölés az ábrákon & Személyek száma (fő) \\
\hline Legfelsô szint (első számú vezető) & A & 1 \\
\hline Második szint (első számú vezető helyettesei) & B & 4 \\
\hline Harmadik szint (önálló területek felelôs vezetôi I.) & C & 5 \\
\hline Negyedik szint (önálló területek felelős vezetői II.) & D & 11 \\
\hline Összesen & & 21 \\
\hline
\end{tabular}

2. táblázat

A funkció-szerep alapú kritériumok esetében kapott választások száma és aránya szerint sorrendek

\begin{tabular}{|c|c|c|c|c|c|c|c|c|}
\hline \multicolumn{3}{|c|}{ Elismert szakember } & \multicolumn{3}{|c|}{ Népszerû vezető } & \multicolumn{3}{|c|}{ Vállalkozó szellem } \\
\hline Sorrend & $\begin{array}{c}\text { Kapott } \\
\text { választások } \\
\text { száma }\end{array}$ & $\begin{array}{c}\text { Kapott } \\
\text { választások } \\
\%\end{array}$ & Sorrend & $\begin{array}{c}\text { Kapott } \\
\text { választások } \\
\text { száma }\end{array}$ & $\begin{array}{c}\text { Kapott } \\
\text { választások } \\
\%\end{array}$ & Sorrend & $\begin{array}{c}\text { Kapott } \\
\text { választások } \\
\text { száma }\end{array}$ & $\begin{array}{c}\text { Kapott } \\
\text { választások } \\
\%\end{array}$ \\
\hline A1 & 20 & 34 & A1 & 16 & 30 & A1 & 19 & 35 \\
\hline $\mathrm{C} 2$ & 7 & 12 & D5 & 6 & 11 & $\mathrm{C4}$ & $=10$ & 18 \\
\hline D6 & 5 & 8 & B2 & 5 & 9 & D6 & 6 & 11 \\
\hline $\mathrm{C4}$ & 5 & 8 & B3 & 5 & 9 & B4 & 5 & 9 \\
\hline $\mathrm{C} 1$ & 5 & 8 & D6 & 4 & 8 & $\mathrm{C} 2$ & 4 & 7 \\
\hline D3 & 5 & 8 & B4 & 3 & 6 & D3 & 2 & 4 \\
\hline D7 & 2 & 3 & D7 & 3 & 6 & D1 & 2 & 4 \\
\hline D5 & 2 & 3 & D8 & 3 & 6 & D7 & 1 & 2 \\
\hline B2 & 2 & 3 & D2 & 3 & 6 & C5 & 1 & 2 \\
\hline $\mathrm{C} 3$ & 2 & 3 & B1 & 2 & 4 & D5 & 1 & 2 \\
\hline D1 & 2 & 3 & $\mathrm{C} 4$ & 1 & 2 & D9 & 1 & 2 \\
\hline $\mathrm{C5}$ & 1 & 2 & D3 & 1 & 2 & B2 & 1 & 2 \\
\hline B3 & 1 & 2 & D1 & 1 & 2 & $\mathrm{C3}$ & 1 & 2 \\
\hline B4 & 0 & 0 & $\mathrm{C} 2$ & 0 & 0 & D11 & 1 & 2 \\
\hline D10 & 0 & 0 & D10 & 0 & 0 & D10 & 0 & 0 \\
\hline B1 & 0 & 0 & $\mathrm{C} 1$ & 0 & 0 & $\mathrm{C} 1$ & 0 & 0 \\
\hline D8 & 0 & 0 & C5 & 0 & 0 & B1 & 0 & 0 \\
\hline D9 & 0 & 0 & D9 & 0 & 0 & D8 & 0 & 0 \\
\hline D4 & 0 & 0 & D4 & 0 & 0 & D4 & 0 & 0 \\
\hline D11 & 0 & 0 & $\mathrm{C} 3$ & 0 & 0 & B3 & 0 & 0 \\
\hline D2 & 0 & 0 & D11 & 0 & 0 & D2 & 0 & 0 \\
\hline $\begin{array}{l}\text { Összes } \\
\text { adott } \\
\text { választás }\end{array}$ & 59 & 100 & $\begin{array}{c}\text { Összes } \\
\text { adott } \\
\text { választás }\end{array}$ & 53 & 100 & $\begin{array}{c}\text { Összes } \\
\text { adott } \\
\text { választás }\end{array}$ & 55 & 100 \\
\hline
\end{tabular}


A vizsgált személyek szervezeti hierarchia és szociometriai státus-hierarchia szerinti kombinált gyakorisági megoszlása

\begin{tabular}{|l|c|c|c|c|c|}
\hline \multirow{2}{*}{$\begin{array}{l}\text { Szervezeti } \\
\text { hierarchia }\end{array}$} & $\begin{array}{c}\text { 4. (legfelső) } \\
\text { kvartilis }\end{array}$ & 3. kvartilis & 2. kvartilis & $\begin{array}{c}\text { 1. (legalsó) } \\
\text { kvartilis }\end{array}$ & Összesen \\
\cline { 2 - 6 } „A" szint & 1 & & & & $\mathbf{1}$ \\
\hline „B" szint & 1 & 1 & 2 & & $\mathbf{4}$ \\
\hline „C" szint & 1 & 1 & 2 & 1 & $\mathbf{5}$ \\
\hline „D” szint & 2 & 2 & 3 & 4 & $\mathbf{1 1}$ \\
\hline Összesen & $\mathbf{5}$ & $\mathbf{4}$ & $\mathbf{7}$ & $\mathbf{5}$ & $\mathbf{2 1}$ \\
\hline
\end{tabular}

4. táblázat

Az összes értékelő által adott értékelés adatai az átlagok csökkenő sorrendjében

\begin{tabular}{|l|c|c|c|c|}
\hline Kompetencia & $\begin{array}{c}\text { Értékelt személyek } \\
\text { száma }\end{array}$ & Átlag & Szórás & $\begin{array}{c}\text { Relatív } \\
\text { szórás \% }\end{array}$ \\
\hline Szakterületi tudás & 21 & $\mathbf{3 , 2 6}$ & 0,42 & 13 \\
\hline Elkötelezettség & 21 & $\mathbf{3 , 1 4}$ & 0,35 & 11 \\
\hline Külső ügyfél-orientáltság & 21 & $\mathbf{3 , 1 2}$ & 0,68 & 22 \\
\hline Eredményorientáltság & 21 & $\mathbf{3 , 0 4}$ & 0,40 & 13 \\
\hline Operativitás & 21 & $\mathbf{2 , 8 9}$ & 0,49 & 17 \\
\hline Fejlődố képesség & 21 & $\mathbf{2 , 8 7}$ & 0,32 & 11 \\
\hline Iparági szemlélet & 21 & $\mathbf{2 , 8 7}$ & 0,51 & 18 \\
\hline Kockázat-megítélési képesség & 21 & $\mathbf{2 , 8 7}$ & 0,51 & 18 \\
\hline Minốség, kiválóság iránti elkötelezettség & 21 & $\mathbf{2 , 8 6}$ & 0,46 & 16 \\
\hline Információtovábbítás, információkezelés & 21 & $\mathbf{2 , 8 5}$ & 0,51 & 18 \\
\hline Fejlesztés-támogatás & 21 & $\mathbf{2 , 8 4}$ & 0,40 & 14 \\
\hline Belső ügyfél-orientáltság & 21 & $\mathbf{2 , 7 7}$ & 0,69 & 25 \\
\hline Munkaszervezés & 21 & $\mathbf{2 , 7 5}$ & 0,43 & 16 \\
\hline Delegálás & 21 & $\mathbf{2 , 7 3}$ & 0,31 & 11 \\
\hline Hitelesség & 21 & $\mathbf{2 , 6 9}$ & 0,62 & 23 \\
\hline Csapatmunka & 21 & $\mathbf{2 , 6 9}$ & 0,63 & 23 \\
\hline Felelósségvállalás & 21 & $\mathbf{2 , 6 8}$ & 0,43 & 16 \\
\hline Változáskezelés & 21 & $\mathbf{2 , 6 7}$ & 0,36 & 14 \\
\hline Motiválás & 21 & $\mathbf{2 , 5 5}$ & 0,47 & 18 \\
\hline Üzletorientáció & 21 & $\mathbf{2 , 5 2}$ & 0,54 & 21 \\
\hline Kommunikációs stílus & 21 & $\mathbf{2 , 5 0}$ & 0,69 & 28 \\
\hline Rugalmasság, alkalmazkodó képesség & 21 & $\mathbf{2 , 5 0}$ & 0,58 & 23 \\
\hline Innovativitás & 21 & $\mathbf{2 , 4 9}$ & 0,47 & 19 \\
\hline Vállalkozó szellem, kockázatvállalás & 21 & $\mathbf{2 , 2 6}$ & 0,72 & 32 \\
\hline
\end{tabular}


A kompetenciák szintjének megítélése az egyes értékelői relációkból (átlagértékek)

\begin{tabular}{|c|c|c|c|c|}
\hline Kompetencia & $\begin{array}{c}\text { Összes értékelỏ } \\
\text { szerint }\end{array}$ & $\begin{array}{l}\text { Felettes értékelői } \\
\text { relációból }\end{array}$ & $\begin{array}{l}\text { Oldalági értékelői } \\
\text { relációból }\end{array}$ & $\begin{array}{l}\text { Beosztott értékelői } \\
\text { relációból }\end{array}$ \\
\hline Eredményorientáltság & 3,04 & 3,26 & 2,72 & 3,02 \\
\hline Vállalkozó szellem, kockázatvállalás & 2,26 & 2,23 & 1,98 & 2,40 \\
\hline Minőség, kiválóság iránti elkötelezettség & 2,86 & 3,22 & 2,67 & 2,77 \\
\hline Kockázat-megítélési képesség & 2,87 & 2,62 & 2,68 & 3,06 \\
\hline Iparági szemlélet & 2,87 & 2,70 & 2,53 & 3,10 \\
\hline Szakterületi tudás & 3,26 & 3,32 & 3,06 & 3,27 \\
\hline Üzletorientáció & 2,52 & 2,41 & 2,27 & 2,68 \\
\hline Felelősségvállalás & 2,68 & 2,85 & 2,08 & 2,85 \\
\hline Hitelesség & 2,69 & 3,00 & 2,42 & 2,71 \\
\hline Elkötelezettség & 3,14 & 3,41 & 2,83 & 3,18 \\
\hline Rugalmasság, alkalmazkodó képesség & 2,50 & 2,50 & 2,28 & 2,61 \\
\hline Innovativitás & 2,49 & 2,43 & 2,23 & 2,59 \\
\hline Változáskezelés & 2,67 & 2,66 & 2,48 & 2,73 \\
\hline Fejlődő képesség & 2,87 & 2,86 & 2,54 & 3,01 \\
\hline Csapatmunka & 2,69 & 2,93 & 2,50 & 2,69 \\
\hline Külső ügyfél-orientáltság & 3,12 & 3,10 & 2,87 & 3,28 \\
\hline Belső ügyfél-orientáltság & 2,77 & 2,72 & 2,59 & 2,95 \\
\hline Információtovábbítás, információkezelés & 2,85 & 3,23 & 2,63 & 2,77 \\
\hline Kommunikációs stílus & 2,50 & 2,33 & 2,50 & 2,61 \\
\hline Munkaszervezés & 2,75 & 2,77 & 2,67 & 2,69 \\
\hline Operativitás & 2,89 & 2,88 & 2,70 & 2,90 \\
\hline Delegálás & 2,73 & 2,65 & 2,70 & 2,76 \\
\hline Motiválás & 2,55 & 2,52 & 2,36 & 2,66 \\
\hline Fejlesztés-támogatás & 2,84 & 2,93 & 2,60 & 2,90 \\
\hline
\end{tabular}

A felettes és az oldalági relációban adott átlagok összehasonlítása

\begin{tabular}{|c|c|c|}
\hline \multicolumn{3}{|c|}{ Azoknak a kompetenciáknak a száma, amelyek esetében } \\
\hline $\begin{array}{l}\text { a felettes relációban magasabb átlagok } \\
\text { születtek, mint az oldalágiban }\end{array}$ & $\begin{array}{l}\text { a felettes és az oldalági relációban szüle- } \\
\text { tett átlagok különbsége elhanyagolható }\end{array}$ & $\begin{array}{l}\text { az oldalági relációban magasabb átlagok } \\
\text { születtek, mint a felettesiben }\end{array}$ \\
\hline 21 & $\mathbf{2}$ & $\mathbf{1}$ \\
\hline
\end{tabular}

\section{A felettes és a beosztott relációban adott átlagok összehasonlítása}

\begin{tabular}{|c|l|l|}
\hline \multicolumn{3}{|c|}{ Azoknak a kompetenciáknak a száma, amelyek esetében } \\
\hline $\begin{array}{l}\text { a felettes relációban magasabb átlagok } \\
\text { születtek, mint a beosztottiban }\end{array}$ & $\begin{array}{l}\text { a felettes és a beosztotti relációban született } \\
\text { átlagok különbsége elhanyagolható }\end{array}$ & $\begin{array}{l}\text { a beosztotti relációban magasabb átlagok } \\
\text { születtek, mint a felettesiben }\end{array}$ \\
\hline $\mathbf{6}$ & $\mathbf{6}$ & $\mathbf{1 2}$ \\
\hline
\end{tabular}


Az oldalági és a beosztotti relációban adott átlagok összehasonlítása

\begin{tabular}{|c|c|c|}
\hline \multicolumn{3}{|c|}{ Azoknak a kompetenciáknak a száma, amelyek esetében } \\
\hline $\begin{array}{l}\text { az oldalági relációban magasabb átlagok } \\
\text { születtek, mint a beosztottiban }\end{array}$ & $\begin{array}{l}\text { az oldalági és a beosztotti relációban szü- } \\
\text { letett átlagok különbsége elhanyagolható }\end{array}$ & $\begin{array}{l}\text { a beosztotti relációban magasabb átlagok } \\
\text { születtek, mint az oldalágiban }\end{array}$ \\
\hline $\mathbf{0}$ & $\mathbf{2}$ & $\mathbf{2 2}$ \\
\hline
\end{tabular}

A legmagasabb és a legalacsonyabb szociometriai státusú személyek kompetenciaszintjeinek adatai az összes értékelő szerint

\begin{tabular}{|c|c|c|c|}
\hline. & $\begin{array}{l}\text { Legmagasabb } \\
\text { szociometriai státusúak } \\
n=5\end{array}$ & $\begin{array}{l}\text { Legalacsonyabb } \\
\text { szociometriai státusúak } \\
n=5\end{array}$ & $\begin{array}{c}\text { A kompetencia átlagok } \\
\text { különbsége a legmagasabb és a } \\
\text { legalacsonyabb szociometriai } \\
\text { státusúak között }\end{array}$ \\
\hline Üzletorientáció & 2,82 & 2,23 & 0,59 \\
\hline Szakterületi tudás & 3,56 & 2,98 & 0,58 \\
\hline Külső ügyfél-orientáltság & 3,45 & 2,90 & 0,56 \\
\hline Vállalkozó szellem, kockázatvállalás & 2,77 & 2,22 & 0,55 \\
\hline Operativitás & 3,19 & 2,73 & 0,47 \\
\hline Iparági szemlélet & 2,99 & 2,56 & 0,43 \\
\hline Fejlődő képesség & 3,02 & 2,63 & 0,40 \\
\hline Rugalmasság, alkalmazkodó képesség & 2,79 & 2,43 & 0,37 \\
\hline Innovativitás & 2,77 & 2,40 & 0,37 \\
\hline Fejlesztés-támogatás & 3,01 & 2,68 & 0,33 \\
\hline Eredményorientáltság & 3,31 & 2,98 & 0,33 \\
\hline Felelősségvállalás & 2,89 & 2,56 & 0,33 \\
\hline Elkötelezettség & 3,29 & 2,97 & 0,32 \\
\hline Csapatmunka & 3,00 & 2,69 & 0,31 \\
\hline Motiválás & 2,92 & 2,65 & 0,27 \\
\hline Kommunikációs stílus & 2,82 & 2,55 & 0,27 \\
\hline Kockázat-megítélési képesség & 3,11 & 2,86 & 0,24 \\
\hline Változáskezelés & 2,86 & 2,67 & 0,19 \\
\hline Információtovábbítás, információkezelés & 2,94 & 2,79 & 0,15 \\
\hline Belső ügyfél-orientáltság & 2,99 & 2,84 & 0,15 \\
\hline Munkaszervezés & 2,97 & 2,86 & 0,10 \\
\hline Minőség, kiválóság iránti elkötelezettség & 2,84 & 2,79 & 0,06 \\
\hline Hitelesség & 2,70 & 2,70 & 0,00 \\
\hline Delegálás & 2,65 & 2,84 & $-0,19$ \\
\hline
\end{tabular}


A legmagasabb szociometriai státusú 4 személy és az első számú vezető (A1) kompetenciaszintjeinek adatai az összes értékelő szerint

\begin{tabular}{|c|c|c|c|}
\hline & $\begin{array}{l}\text { Legmagasabb } \\
\text { szociometriai státusúak } \\
\text { az elsô számú vezetô } \\
\text { (A1) nélkül } n=4\end{array}$ & $\begin{array}{l}\text { Első számú vezető } \\
\text { (A1) }\end{array}$ & $\begin{array}{c}\text { A kompetencia átlagok } \\
\text { különbsége a legmagasabb } \\
\text { szociometriai státusú } 4 \text { személy } \\
\text { és az első számú vezető } \\
\text { (A1) között }\end{array}$ \\
\hline Iparági szemlélet & 2,74 & 4,00 & 1,26 \\
\hline Vállalkozó szellem, kockázatvállalás & 2,54 & 3,71 & 1,18 \\
\hline Üzletorientáció & 2,60 & 3,71 & 1,12 \\
\hline Operativitás & 3,03 & 3,86 & 0,83 \\
\hline Innovativitás & 2,60 & 3,43 & 0,83 \\
\hline Eredményorientáltság & 3,17 & 3,86 & 0,69 \\
\hline Felelősségvállalás & 2,76 & 3,43 & 0,67 \\
\hline Kockázat-megítélési képesség & 2,99 & 3,57 & 0,58 \\
\hline Fejlődổ képesség & 2,92 & 3,43 & 0,51 \\
\hline Szakterületi tudás & 3,48 & 3,86 & 0,37 \\
\hline Rugalmasság, alkalmazkodó képesség & 2,74 & 3,00 & 0,26 \\
\hline Delegálás & 2,60 & 2,86 & 0,25 \\
\hline Kommunikációs stílus & 2,77 & 3,00 & 0,23 \\
\hline Munkaszervezés & 2,92 & 3,14 & 0,22 \\
\hline Változáskezelés & 2,82 & 3,00 & 0,18 \\
\hline Elkötelezettség & 3,25 & 3,43 & 0,17 \\
\hline Fejlesztés-támogatás & 2,98 & 3,14 & 0,17 \\
\hline Hitelesség & 2,69 & 2,71 & 0,02 \\
\hline Külső ügyfél-orientáltság & 3,46 & 3,43 & $-0,03$ \\
\hline Motiválás & 2,94 & 2,86 & $-0,08$ \\
\hline Minőség, kiválóság iránti elkötelezettség & 2,91 & 2,57 & $-0,34$ \\
\hline Belső ügyfél-orientáltság & 3,07 & 2,67 & $-0,40$ \\
\hline Információtovábbítás, információkezelés & 3,03 & 2,57 & $-0,46$ \\
\hline Csapatmunka & 3,10 & 2,57 & $-0,53$ \\
\hline
\end{tabular}

